\title{
Enhancing Most Essential Learning Competency (Melc) in English 9 Using The Skills-Based Learning Material
}

\author{
Ailene R. Lumanog1, Myrna 0. Medrano² \\ ${ }^{1}$ Southville I Integrated National High School, Philippines \\ ${ }^{2}$ Laguna State Polytechnic University, Los Baños Campus, Philippines
}

\begin{abstract}
The skills-based learning material was made and studied by the researcher due to sudden changes in education in a time of the pandemic. The main focus of this study is to determine the effectiveness of the skillsbased learning material for English 9. This study used the pretest-posttest non-equivalent control group design, which falls under the quasi-experimental design. On the test of significant difference between the formative mean scores of the experimental and comparison groups, it was found out that the formative tests had a significant effect on the respondents' learning performance at $\mathrm{p} 0.01$ level. Additionally, the posttest mean scores of each group; got the 0.01 level of significance, as well as the pretest and posttest mean scores of each group. Moreover, based on the computed Cohen's $d$ value of 1.16, the effect size of the learning material to the students' performance is large compared to the comparison group that shows a small effect size at 0.31 Cohen's $d$ value. Generally, there is a significant difference between the formative test of the two groups with the average and high mean scores, respectively. There is also a significant difference between the posttest mean scores of the two groups and as well between the pre-test and post-test mean scores. Moreover, Cohen's effect size value of 1.16 suggested a large effect of the material on the respondents' learning performance. As for recommendations, there is a need for the teacher to incorporate the 21st Century Skills into learning competencies.
\end{abstract}

Keywords: skills-based learning material, learning performance

This is an open-access article under the CC-BY-NC license.

\section{INTRODUCTION}

Education is seen as an important means to improve human resources that eventually affect the sustainable, inclusive development of all countries. Global policymakers also consider education as one of the enabling factors that contribute to achieving inclusive growth. In fact, as UNDP (2019) explained, attaining comprehensive and excellent education among students revalidates the notion that education is a great and proven means for viable development.

In doing so, these global policymakers and educational planners have seen the potentials of Sustainable Development Goal 4- Quality to increase opportunities for all people as they have acquired necessary learning competencies relevant to survive in the rapid-changing world. Following the 2030 Agenda for Sustainable Development that ensures that no one is left behind because of its universality, many countries have continuously improved the delivery of instruction to the students regardless of their internal and external differences.

Various provisions and policies have been enacted to support this global call for quality and inclusive education. Ferguson et al. (2019) also explained that education is the most critical among the goals as it could open work opportunities for persons that could give a solution for unemployment and poverty; it can lessen societal discriminations and offer the knowledge and skills needed to live in sustainable lifestyles. That goal covers the kindergarten and at least high school education and to more advanced training for skills with the Corresponding author Ailene R. Lumanog,ailene.lumanog@deped.gov.ph DOI: https://doi.org/10.31098/ijtaese.v3i2.631 
International Journal of Theory and Application in Elementary and Secondary School Education (IJTAESE), Vol. 3 (2), 51-60

Enhancing Most Essential Learning Competency (Melc) in English 9 Using The Skills-Based Learning Material

Ailene R. Lumanog, Myrna O. Medrano

main goal of facilitating the realization of the full potentials of individuals to contribute to forming a fair, humane, and compassionate world (Sachs, 2015).

In the Philippines, the Department of Education (DepEd), being the highest governing agency in the education sector, has initiated various national policies to adhere to the target goals of Sustainable Education 4. In fact, the DepEd focuses on its mission to defend and support the right of every Filipino to quality, equitable, culture-based, and complete basic education. Such drive of the governing agency has been felt through the institutionalization of K-12 curriculum to provide significant reform to the educational system of the country. Since the inception of the K-12 curriculum, there have been educational efforts that have been in place to cater to the diverse needs of the students, at the same time, to respond to the global demands.

To realize the goals of the K-12 curriculum, learning activities must be consistently reviewed and further enhanced to keep them with the pace of globalized demands. Incorporating the 21st-century skills into the K-12 learning standards would be necessary for making learners globally competitive individuals and ready to face the challenges brought about by the extreme effects of globalization. According to Bybee (2013), as cited by Stehle \& Peters-Burton (2019), it is necessary to guarantee that basic education graduate students are competent in the 21st Century skills for them to succeed in their future careers. These 21st Century skills would not only support students to become successful in their schooling, but these are also essential for them to adjust and succeed in a continuously changing world (Partnership for 21st Century Learning, 2016).

The requirement to integrate 21st-century skills in educational parlance was examined and explained by various authors and researchers. Dede (2010) argued that the capabilities essential in the 21st century is not the same as the 20th. The skills requirements needed for employment, social responsibility, and selfactualization were not the same a decade ago. Levin-Goldberg (2012) explained that the 21st Century global demand is focused on creativity and innovation, where people are expected to be critical thinkers and problems solvers, communicators, and team workers; therefore, it is expected to teach the learners the 4Cs; where they will utilize technology and be logical. It was seemed to be an effective means to prepare learners for the global community despite the worldwide adversities that have been experienced by all individuals regardless of their multifactorial differences.

Besides, Ross (2017) also stressed the significance of the 4Cs in the success of the learners in school, work, and life opportunities. It also ensures global competitiveness and the nation's well-being. This also prepares the learners to become good members of the society - one who involves socially, thinks critically, is technologically literate, aware globally, and communicates effectively. Furthermore, Bialik et al. (2015) explained the needs in addressing the ultimate question of "WHAT should students learn for the 21st century?". It was explained that aside from the employment opportunities and the technology's exponential growth due to globalization and innovation, people are facing serious challenges in society, economy, and personal aspects. These are the instability in finances, change in climate, and invasions of personal privacy, and with narrow-mindedness expressed in religious ideology, cultural discrimination, and political tyranny. These will be addressed through redesigning the curriculum where learners will be a problem- solvers, critical and creative thinkers, good communicators, and productive members of society.

Even in language learning, EFL should not simply give emphasis on the development of students' skills in using the language but should also focus on incorporating the 4Cs into the learning procedure to meet the challenges instigated by globalization and digitalization in the 21st century (Pardede, 2020). Halvorsen (2018) also discussed the skills in 21st Century and the "4Cs" in the English Language Classroom. She stated that the 4C's is stimulated when learners are requested to investigate a topic, deliberate or give an argument on a specific topic with the group, and note the things they learned and found out through the application of the 4Cs in the English classroom. 
International Journal of Theory and Application in Elementary and Secondary School Education (IJTAESE), Vol. 3 (2), 51-60

Enhancing Most Essential Learning Competency (Melc) in English 9 Using The Skills-Based Learning Material

Ailene R. Lumanog, Myrna O. Medrano

Moreover, Chong (2018), in her article regarding the development and advances in language education, shared that technology innovations made teachers combine digital media in their traditional teaching and try to make it more interesting by giving practical online activities. Even the use of different Learning Management Platforms (LMSs) was discussed, where handouts and online activities and discussions can be found. Another is Embodied Learning which deepens learning by not only recalling but also includes concentration, collaboration, discussion, and exploration. According to Chong (2018), learners must engage their emotions, intellect, physical and social in learning the language. Additionally, Spearce (2021) discussed virtual reality in education, task-based learning (collaboration on meaningful and communication-based tasks), and DIY/ engagement learning as the latest trends of education for the 21st Century.

With these situations, the researcher intended to enhance the essential learning competencies in English through incorporating 21st-century skills such as critical thinking, creativity, communication, and collaboration into the learning activities suggested by the present learning module. Through the developed learning module, the researcher also determined the effectiveness of the skills-based learning approach as a valid and reliable approach to use in instructional management and development, ensuring the learners would become globally competitive and functionally literate who are also well-equipped with appropriate knowledge, skills, and values.

\section{RESEARCH METHOD}

This study utilized a quasi-experimental design to determine the effectiveness of the skills-based learning module. Following the procedures of the research design, the respondents consisting of 36 Grade 9 students were grouped into two groups: the comparison and the experimental group. The members of each group were determined through match pairing, which was done by conducting a pre-test among the students in an online class of Grade 9 and the students under the blended online class. The experimental group used the researcher-developed skills-based learning material, while the comparison group used the knowledgebased DepEd PIVOT 4A Learner's Material for English 9. At the end of each session, formative tests were given to monitor the effects of the material on the respondents' learning performance. At the end of the lesson, both the experimental and comparison groups were given a post-test to measure the effectiveness of the said material in the achievement of the specific competency through Blended Online Delivery Learning.

As for the research instruments, the researchers utilized three instruments: a test to measure the learning outcome, which was used as the pretest and the post-test (consisted of twenty (50) multiple-choice items), the skills-based learning material itself, and the evaluation tool that measured the acceptability of the skills-based material. With regard to the content of the assessment tools, the questions were based on the student's takeaways from the lesson presented in the material. This measured the mastery in the required competency to determine the relevance and truthfulness of the ideas presented in the material viewed. In contrast, the skills-based material consisted of a collection of the validated materials for 4C's of 21st Century Learning and material for listening, reading, and viewing. These materials, such as videos and texts, were borrowed from online platforms.

However, the formative assessment included in the material was the researcher made activities/questions. Each formative test consists of twenty (20) items. The researcher-made formative questions must be answered right after each lesson presentation. Additionally, the material consisted of lessons presented in two forms, such as reading and the combined listening and viewing material. The skillsbased material is once again consisting of activities aligned on the IDEAS approach (Introduction, Development, Engagement and Enhancement, Assessment and Synthesis). To determine the acceptability of the skills-based learning module, the researcher used an evaluation tool that focused on the content, language, 
organization, selection of activities, and assessment. The experimental group rated the said module based on the above-mentioned criteria with 1 (strongly disagree) and 5 (strongly agree).

Furthermore, to assure that the ethical standards were sustained throughout the course of the study, the researcher gave attention to the ethical procedures enumerated by Bryman and Bell (2007). To show respect, the researcher personally sought the permission of the concerned individuals and institutions to conduct the study and to explain and obtain informed consent to and from the respondents of the study. Moreover, the researcher promoted the well-being of the respondents, and the use of offensive, discriminatory, or other unacceptable language was avoided.

For the treatment and analysis of data, the descriptive statistics used in this study were frequency count, percentage, and weighted mean, and standard deviation. These statistics were used to describe the respondents in terms of their comprehension level, as well as to describe the scores obtained from their pretest and post-test. Also, an Independent t-test was used to determine whether or not there is a significant difference in the formative test mean scores of the experimental and comparison groups. It was also used to determine whether or not there is a significant difference in the mean post-test scores of the two groups. In addition, the Paired t-test was used to determine whether or not there is a significant difference in the performance of the learners between the pre-test and post-test means scores of both groups. The hypothesis stating that there is no significant difference between the performance of the experimental and comparison groups was tested at .05 level. Also, Cohen's d was used to measure the effectiveness of the skills-based learning material in enhancing the essential learning competency.

\section{FINDINGS AND DISCUSSION}

The data were collected through a series of tests: a pre-test, two formative tests, and a post-test. These were tabulated and interpreted to solve the problems of the study.

Table 1. Pretest mean scores of the experimental and comparison groups

\begin{tabular}{llllll}
\hline Group & Min. & Max. & Mean & Std. Dev. & $\begin{array}{l}\text { Descriptive } \\
\text { Interpretation }\end{array}$ \\
\hline Experimental Group & 7 & 42 & 27.14 & 9.44 & Average \\
Comparison Group & 7 & 42 & 27.14 & 9.44 & Average \\
\hline
\end{tabular}

Total number of possible points $=50$

Legend: 45- 50 = Very High; 35 - 44 = High; 25 - 34 = Average; 15 - 24 = Low; 1 - 14 = Very Low

Table 1 shows the pretest mean scores of the experimental and comparison groups. The pretest assessed the existing knowledge of the students on the upcoming lesson. Moreover, it reports that out of the 50 items in the pretest, the highest and lowest scores that the respondents from each group got were 42 and 7, respectively, both with the mean of 27.14 with a descriptive interpretation of average. Additionally, the scores in each group report a standard deviation value of 9.44 , which determines the distribution of the scores with relation to the mean. 
International Journal of Theory and Application in Elementary and Secondary School Education (IJTAESE), Vol. 3 (2), 51-60

Enhancing Most Essential Learning Competency (Melc) in English 9 Using The Skills-Based Learning Material Ailene R. Lumanog, Myrna O. Medrano

Table 2. Formative test mean scores of the students in the experimental and comparison groups

\begin{tabular}{lllllll}
\hline Lesson & Group & Min. & Max. & Mean & $\begin{array}{l}\text { Std. } \\
\text { Dev. }\end{array}$ & $\begin{array}{l}\text { Descriptive } \\
\text { Interpretation }\end{array}$ \\
\hline 1 & 12 & 20 & 17.14 & 2.66 & High \\
& $\begin{array}{l}\text { Experimental } \\
\text { Group }\end{array}$ & 11 & 18 & 14.93 & 2.37 & Average \\
$\begin{array}{l}\text { Comparison } \\
\text { Group }\end{array}$ & 14 & 20 & 17.86 & 2.38 & High \\
\hline 2 & $\begin{array}{l}\text { Experimental } \\
\text { Group }\end{array}$ & 15 & 20 & 15.36 & 3.73 & Average \\
& $\begin{array}{l}\text { Comparison } \\
\text { Group }\end{array}$ & 8 & & & & \\
\hline
\end{tabular}

Total number of possible points in each formative test $=20$

Legend: $18.00-20.00$ = Very High; $16.00-17.00=$ High; $10.00-15.00=$ Average; $6.00-9.00=$ Low; $1.00-$ $5.00=$ Very Low

Table 2 presents the formative test mean scores of the students in the experimental and comparison groups. The first formative test aimed to determine the tone, mood, technique, and purpose of the author in the given selection. Aside from determining the tone, mood, and author's purpose, the second formative test aimed to interpret and appreciate the message conveyed in the given audio-visual materials. In the first formative test, the respondents encountered five different selections to read and analyze. While in the second formative test, the respondents were shown video advertisement, poem recital, play, and explanatory video for them to interpret. Thus, it reports that the respondents in the experimental group, which had utilized the skills-based material, obtained a high mean score on the first and the second formative tests, 17.14 and 17.86, while those in the comparison group obtained average mean scores of 14.93 and 15.36.

Moreover, the standard deviation values of both groups in the first formative test indicate that the scores of the respondents in the experimental group are more spread out compared to those in the comparison group. While, in the second formative test indicate that the scores of the respondents in the experimental group are less spread out compared to those in the comparison group.

This result is parallel with the findings of Nurhana (2014) in his study. It was found out that the experimental group had a significant increase in the learning performance during the implementation process from the formative test mean scores of 72.1 increased to 81.3.

Table 3. Posttest mean scores of the students in the experimental and comparison groups

\begin{tabular}{llllll}
\hline Group & Min. & Max. & Mean & Std. Dev. & $\begin{array}{l}\text { Descriptive } \\
\text { Interpretation }\end{array}$ \\
\hline Experimental Group & 25 & 48 & 37.36 & 8.11 & High \\
Comparison Group & 14 & 46 & 30.00 & 8.79 & Average \\
\hline
\end{tabular}

Total number of possible points $=50$

Legend: $45-50$ = Very High; 35 - 44 = High; 25 - 34 = Average; 15 - 24 = Low; 1 - 14 = Very Low

Table 3 presents the posttest mean scores of the experimental and comparison groups. The posttest assessed the mastery of the respondents in the learning competency, where they determined the relevance and truthfulness of the ideas presented in the material viewed. It shows that the highest score obtained in the experimental group is 48 and the lowest score obtained is 25 . On the other hand, the highest score obtained 
in the comparison group is 46 , and the lowest is 14 . Furthermore, the table indicates that the respondents in the experimental group obtained a high mean score of 37.36, while those in the comparison group obtained an average mean score of 30.00 . Furthermore, the standard deviation values of both groups indicate that the scores of the respondents in the experimental group are less spread out compared to those in the comparison group.

These results support the findings of Corpuz-Bullecer (2017) in his study. It was found out that the use of skills-based activities significantly enhances the student's higher-order thinking skills and learning performance.

Table 4. Test of significant difference between the formative test mean scores of the students in the experimental and comparison groups

\begin{tabular}{|c|c|c|c|c|c|c|}
\hline Test & Group & Mean & $\begin{array}{l}\text { Mean } \\
\text { Difference }\end{array}$ & $\mathrm{df}$ & t-value & p-value \\
\hline Formative 1 & $\begin{array}{l}\text { EG } \\
\text { CG }\end{array}$ & $\begin{array}{l}17.14 \\
14.93\end{array}$ & 2.21 & 26 & 2.33 & .003 \\
\hline Formative 2 & $\begin{array}{l}\text { EG } \\
\text { CG }\end{array}$ & $\begin{array}{l}17.86 \\
15.36\end{array}$ & 2.50 & 26 & 2.11 & .004 \\
\hline
\end{tabular}

Legend: $\mathrm{EG}=$ Experimental Group; $\mathrm{CG}$ = Comparison Group; $\mathrm{df}=$ Degrees of Freedom

**Significant at .01 level

Table 4 shows the test of significant difference between the formative test mean scores of the experimental and comparison groups. It reports the mean difference values of 2.21 and 2.50 for the two formative tests. Furthermore, the two formative tests have a p-value of 0.003 and 0.004 , respectively, which makes them significant at p 0.01 level. Moreover, the two formative tests have a p-value of 0.003 and 0.004 , respectively, which makes them significant at p 0.01 level.

Table 5. Test of significant difference between the posttest mean scores of the students in the experimental and comparison groups

\begin{tabular}{lllllll}
\hline Test & Group & Mean & $\begin{array}{l}\text { Mean } \\
\text { Difference }\end{array}$ & df & t-value & p-value \\
\hline \multirow{2}{*}{ Posttest } & EG & 37.36 & 7.36 & 26 & 2.30 & .003 \\
\hline
\end{tabular}

Legend: $\mathrm{EG}$ = Experimental Group; CG = Comparison Group; $\mathrm{df}$ = Degrees of Freedom

**Significant at .01 level

Table 5 shows the test of significant difference between the posttest mean scores of the experimental and comparison groups. It reports that the mean difference value of the mean posttest scores of the two groups is 7.36. Furthermore, based on the computed t-value of 2.30 and p-value of 0.003 , it can be said that there is a significant difference between the posttest mean scores of the experimental and comparison groups at 0.01 level of significance.

This result reflects the finding of Ashraf (2017). It was revealed that the experimental group that was taught under the 21st-century skills significantly had the higher performance compared to the comparison group. 
International Journal of Theory and Application in Elementary and Secondary School Education (IJTAESE), Vol. 3 (2), 51-60

Enhancing Most Essential Learning Competency (Melc) in English 9 Using The Skills-Based Learning Material

Ailene R. Lumanog, Myrna O. Medrano

Table 6. Test of significant difference between the pretest and posttest mean scores of each group

\begin{tabular}{cllllllll}
\hline Group & Test & Mean & $\begin{array}{l}\text { Mean } \\
\text { Difference }\end{array}$ & df & $\begin{array}{l}\text { t- } \\
\text { value }\end{array}$ & p-value & Cohen's d & $\begin{array}{l}\text { Effect } \\
\text { Size }\end{array}$ \\
\hline \multirow{2}{*}{ CG } & Pretest & 27.14 & 2.86 & 13 & $2.24^{* *}$ & .004 & 0.31 & Small \\
& Posttest & 30.00 & & & & & & \\
\multirow{2}{*}{ EG } & Pretest & 27.14 & 10.21 & 13 & $5.01^{* *}$ & $<.0001$ & 1.16 & Large \\
\hline
\end{tabular}

Legend: $\mathrm{EG}=$ Experimental Group; $\mathrm{CG}=$ Comparison Group

Cohen's d: 0.20 (Small); 0.50 (Medium); 0.80 (Large) $\quad{ }^{* *}$ Significant at .01 level

Table 6 shows the test of significant difference between the pretest and posttest mean scores of each group. It reports that the mean difference value of the mean pretest and posttest scores of the comparison group is 2.86. On the other hand, the mean difference value of the mean pretest and posttest scores of the experimental group is 10.21 which is higher than the mean difference of the comparison group. Furthermore, based on the computed $t$-value of 2.24 and p-value of 0.004 , it can be said that there is a significant difference between the pretest and posttest mean scores of the comparison group at 0.01 level of significance. Moreover, the pretest and posttest mean scores of the experimental group have the greater significance based on the computed t-value of 5.01 and p-value of $<0.0001$ at 0.01 level of significance. Additionally, based on the computed Cohen's d value of 1.16, the effect size of the skills-based learning material on the students' learning performance is large. However, the material utilized by the comparison group shows a small effect size at 0.31 Cohen's d value.

This result reflects the finding of Moradi (2012). It was found out that there was a significant difference between pretest and posttest scores of the experimental group with $t$-value of 4.84, mean difference value of 30 and the $p$-value of $<0.05$. On the other hand, the scores of the comparison group in the pretest and posttest have no significant difference. However, this also contradicts Zobler (2010) findings that the scores of the experimental and control group on the posttest showed no significant difference. Also, the treatment done showed no significant effect on the students' performance.

Table 7. Acceptability of the skills-based learning material

\begin{tabular}{ll}
\hline Evaluation Criteria & Weighted Mean \\
\hline Content & 4.91 \\
Language Used & 4.80 \\
Overall Organization & 4.86 \\
Selection of Activities & 4.83 \\
The Assessment & 4.86 \\
\hline
\end{tabular}

Legend: 5 = Strongly Agree; 4 = Agree; 3 = Neither Agree nor Disagree; 2 = Disagree; 1 = Strongly Disagree

Table 7 shows the acceptability of the skills-based learning material based on the content, language used, overall organization, selection of activities, and the assessment. It shows a strongly agreed acceptability of the skills-based material with the weighted mean scores of $4.91,4.80,4.86,4.83$, and 4.86, respectively. The skills-based learning material consisted of audio-visual materials wherein the Grade 9 students found this effective and engaging. However, in the study of Caspi et al. (2005), it was said that students were interviewed on the use of video recording lectures, and it was found out that the presumed theoretical advantages 
International Journal of Theory and Application in Elementary and Secondary School Education (IJTAESE), Vol. 3 (2), 51-60

Enhancing Most Essential Learning Competency (Melc) in English 9 Using The Skills-Based Learning Material

Ailene R. Lumanog, Myrna O. Medrano

associated with instructional video may, in fact, be disadvantages and the medium does indeed influence the message.

Furthermore, the skills-based learning material enhances 21st-century skills, and as stated by Vivekanandan (2019), 21st-century skills are tools that can be universally applied to enhance ways of thinking, learning, working, and living in the world. The skills include critical thinking/reasoning, creativity/creative thinking, problem-solving, metacognition, collaboration, communication, and global citizenship. The 21st-century skills also include literacies such as reading literacy, writing literacy, numeracy, information literacy, ICT /digital literacy, communication and can be described broadly as learning domains.

\section{CONCLUSION}

Based on the findings of the study, the following conclusions were formulated:

The null hypothesis stating that there is no significant difference between the formative test mean scores of the respondents in the comparison and experimental groups is rejected. The results revealed that the formative test mean score of the experimental group is significantly different compared to the formative test mean score of the comparison group with the p-value of 0.01 level of significance.

Also, the null hypothesis stating that there is no significant difference between the posttest mean scores of the students in the comparison and experimental group under the skills-based learning material is rejected. The results revealed that the mean posttest score of the experimental group is significantly different compared to the mean posttest score of the comparison group based on the computed t-value of 2.30 and pvalue of 0.003 at 0.01 level of significance.

Lastly, the null hypothesis stating that there is no significant difference in the performance of the learners between the pre-test and post-test mean scores of both comparison and experimental groups is rejected. Based on the computed t-value of 2.24 and p-value of 0.004 , it can be said that there is a significant difference between the pretest and posttest mean scores of the comparison group at 0.01 level of significance. Moreover, the pretest and posttest mean scores of the experimental group have the greater significance based on the computed t-value of 5.01 and $p$-value of $<0.0001$ at 0.01 level of significance. Furthermore, the effect size of the skills-based learning material on the students learning performance is large with Cohen's $d$ value of 1.16, while the comparison group showed a small effect size at 0.31 Cohen's $d$ value.

Based on the conclusions of the study, the following recommendations were formulated:

1. With English being one of the fundamental subjects that give literacy, there is a need for the teacher to incorporate and maximize the 21st Century Skills into their learning competencies. This will be through integrating activities that would enhance the learner's critical thinking, creative thinking, collaborative, and communication skills. The 21st-century skills can also be integrated into other subjects. Teachers may use the researcher-developed skills-based learning material as a reference.

2. There is a need for the students to enhance their 21st-century skills through the utilization of the skills-based learning material as a supplementary that will improve their learning performance and prepare themselves for global demands. This will also help them to meet the indispensable competencies included in the Most Essential Learning Competencies (MELC).

3. The school head, instructional managers, and curriculum experts need to strengthen the skillsbased learning system by considering the challenges to be faced by the learners and the need to be independent individuals. This will be their considerations in the development of the curriculum. Thus, education will be more responsive, appropriate, and relevant to the present and future context.

4. Further studies can be conducted to verify the results of this study and widen the scope of the skillsbased learning material, including the whole modules from the first to the fourth quarter, and 
investigate its effectiveness. Also, construct skills-based learning material providing other competencies in English and across grade levels.

\section{REFERENCES}

Ashraf, H., Ahmadi, F., \& Hasseinnia, M. (2017). Integrating 21st Century Skills into Teaching English: Investigating Its Effect on Listening and Speaking Skills. ERIC, 7 (4) 35-43. https://eric.ed.gov/?id=EJ1173769

Bialik, M., et.al (2017). Character Education for the 21st Century: What Should Students Learn?. Center for Curriculum Redesign. https://curriculumredesign.org/wp-content/uploads/CCRCharacterEducation_FINAL_27Feb2015.pdf

Bryman, A.\& Bell, (2007). The Ethics of Management Research: An Exploratory Content Analysis. British Journal of Management,18, 63-77 http://doi.org/10.1111/j.1467-8551.2006.00487.x

Bybee, R. W. (2013). The case for STEM education. Arlington: NSTA Press.

Caspi, A., Gorsky, P. \& Privman, M. (2005). Viewing comprehension: Students' learning preferences and strategies when studying from video. Instr Sci 33, 31-47. https://doi.org/10.1007/s11251-004-2576-x

Chong, C. (2018). Ten trends and innovations in English language teaching for 2018. British Council, https://www.britishcouncil.org/voices-magazine/ten-trends-innovations-english-language-teaching-2018

Corpuz- Bullecer, W. (2017). Viewing Skills: Understanding the Word and the World. Asia Pacific Journal of Multidisciplinary Research, 5 (3). http://www.apjmr.com/wpcontent/uploads/2017/08/APJMR2017.5.3.2.12. pdf

Dede, C. (2010). Comparing frameworks for 21st century skills. 21st century skills: Rethinking how students learn, 20, 51-76.

Ferguson, S. et.al (2019). The Future is Now- Science for Achieving Sustainable Development. University of the West Indies. https://sustainabledevelopment.un.org/content/documents/24797GSDR_report_2019.pdf

Halvorsen, A. (2018). 21st Century Skills and the "4Cs" in the English Language Classroom.https://scholarsbank.uoregon.edu/xmlui/bitstream/handle/1794/23598/halvorsen_21_centur y_skills.pdf?sequence=1\&isAllowed=y

Levin-Goldberg, J. (2012). Teaching Generation TechX with the 4Cs: Using Technology to Integrate 21st Century Skills. Journal of Instructional Research. 1. 59-66. 10.9743/JIR.2013.8.

Moradi, K. (2012). The impact of listening strategy instruction on academic lecture comprehension: A case of Iranian EFL learners. Procedia - Social and Behavioral Sciences, 70, 406-416. https://doi.org/10.1016/j.sbspro.2013.01.078.

Nurhana, R.D. (2014). IMPROVING STUDENTS' READING SKILLS THROUGH INTERACTIVE MULTIMEDIA OF THE 8TH GRADE AT SMP RADEN FATAH CIMANGGU CILACAP IN THE ACADEMIC YEAR OF 2013/2014. English Language Education Department Faculty of Languages and Arts Yogyakarta State University 2014, 64-65

Pardede, P. (2020). Integrating the 4Cs into EFL Integrated Skills Learning. Journal of English Teaching. e-ISSN: 2622-4224 | p-ISSN: 2087-9628

Partnership for 21st Century Learning. (2016). Framework for 21st century learning. Retrieved from www.p21.org/about-us/p21-framework

Ross, D. (2017). Empowering Our Students with 21st-Century Skills for Today. Getting Smart. https://www.gettingsmart.com/2017/04/empowering-students-21st-century-skills/

Sachs, J. (2015). Economist and UN adviser Jeffrey Sachs on why 2015 is critical to setting the world on a safer, more prosperous path. UN News. https://www.un.org/sustainabledevelopment/blog/2015/05/jeffrey-sachs-interview/ 
Spearce, J. (2021). VR, TPRS and Beyond: 6 English Language Teaching

Trends for 2021 You Don't Want to Miss. FluentU, https://www.fluentu.com/blog/educatorenglish/english-language-teaching/

Stehle, S.M. et.al (2019). Developing student 21st Century skills in selected exemplary inclusive STEM high schools. IJ STEM Ed6, 39. https://doi.org/10.1186/s40594-019-0192-1

UNDP. (2019). The Sustainable Development Goals 4- Quality Education. https://www.undp.org/sustainable-development-goals

Vivekanandan, R. (2019). Integrating 21st century skills into education systems: From rhetoric to reality. Education Plus Development

Zobler, A. (2010). "EFFECTS OF LISTENING STRATEGIES INSTRUCTION ON COMPREHENSION, ORAL PROFICIENCY, AND METACOGNITION ON SECOND LANGUAGE LEARNERS". Education Dissertations, 16. https://repository.wcsu.edu/educationdis/16 